\title{
Fair Value Hierarchy and Audit Fees: An Empirical Analysis based on the Listed Banks in China
}

\author{
Zhang Qingyu ${ }^{1, \mathrm{a}}$ \\ ${ }^{1}$ College of finance and accounting, Henan University of Animal Husbandry and Economy, Zhengzhou, Henan, China
}

\begin{abstract}
The key to the criticism of fair value lies in the lack of measurement in the active market quotation, while the fair value hierarchy hopes to make up for the reliability of fair value information by increasing disclosure. Using listed commercial bank data from 2007 through 2016, this paper documents that the assets and liabilities measured by fair value are significantly positively associated with audit fees. The positive association between audit fees and the fair value obtained via Level 2 or Level 3 inputs is greater than that Level 1.These results indicate that when the fair value needs to be estimated, the auditor needs to increase audit effort with resulting in higher audit fees. Moreover, the balance of assets and liabilities that fair-valued using Level 2 inputs is the largest and accounts for the highest proportion, which leads to more substantial changes in audit expenses. This result is consistent with the scale determinism of audit expenses. At the same time, due to the impact of professional judgment on the fair value hierarchy and the absence of corresponding supervision, the management has the motivation to use hierarchy for earnings management. The assets and liabilities that fair-valued using Level 2 inputs may represent the characteristics of fair value earnings management, audit risk is higher.
\end{abstract}

\section{Introduction}

Chinese economic development needs to deepen the reform of the financial system, enhance the financial sector's ability to serve the real economy, increase the proportion of direct financing, and promote the healthy development of the multi-tiered capital market. The effective operation of capital market depends on the quality of information, especially the quality of accounting information. High quality accounting information is the premise of the healthy development of the capital market, which determines the efficiency of market allocation of resources. Audit is one of the effective means to supervise the information quality of the capital market. Although auditors' costs are unobservable, audit fees are highly correlated with proxies for cost drivers: client size, audit risk and audit complexity (Simunic, 1980).

Hay et al. (2006) adopts meta-analysis to evaluate and summarize the research literature on audit expenses over the past 20 years, further proving that the size, business complexity and risks of the auditees have a significant impact on audit expenses, among which the size of the auditees alone can explain more than $70 \%$ of the changes in audit expenses. However, there is uncertainty about the impact of financial leverage and audit opinion on audit expenses. According to Fields et al. (2004), the main factors affecting the audit fees of the banking industry are capital adequacy ratio, liquidity risk, credit risk and other risk factors. Wu Lina (2003) uses the capital market data of China for the first time, and argues that the size of auditees and accounting firm are significantly positively associated with the audit expenses. The return on equity in the qualified range indicates that the company's financial risk is large, the auditor is faced with the risk of audit failure, and there is a negative associated with the audit expenses. According to the research of Pan Keqin (2008), the higher the corporate governance index is, the lower the audit fees is, which means the corporate governance risk is significantly positively associated with the audit expenses. Gai Di and Sheng Changyan (2013) find internal control defects in listed companies, it indicates that internal control risks increase, and auditors will devote greater resources to audit, add substantive testing procedures or charge risk premium, resulting in higher audit fees.

It is found in the literature that there are scale determinism and risk determinism in terms of the importance of audit fees. The determinism of audit fees scale refers to the important role of clients scale in the audit cost pricing. The influencing factors include clients scale (asset scale, total revenue, etc.), number of subsidiaries included in the consolidated statement, number of operating institutions, etc. The larger the client size, whether it is traditional sample audit or possible detailed audit in the case of auditing intelligence, as well as the complexity of the project, the more audit resources need to be paid, and the auditor needs to

ae-mail: 1103498281@qq.com 
increase the audit fees to compensate. Audit fees risk determinism refers to the fact that audit risk plays a decisive role in the pricing of audit cost. The influencing factors include customer business complexity, inherent risk, profitability risk, leverage risk, organizational structure risk and client earnings management risk. Because of the high risk of material misstatement among clients, auditors need to implement more audit procedures to reduce audit risk to an acceptably low level, resulting in higher audit fees.

Fair value accounting aims to improve the relevance of financial reporting information, which is likely to replace historical cost as the main measurement basis of financial reporting (Palea, 2014). Fair value is a kind of valuation based on market information. For assets and liabilities with active market, fair value is measured at market price. When there is no active market, the measurement of fair value adopts the valuation model, which requires the management to make a lot of subjective judgment or choice, and its reliability is relatively weak. At the same time, it also leaves room for the management to maliciously manipulate profits, which is the root cause of the criticism of fair value. How to solve the problem of the reliability of fair value measurement in the absence of market quotation? The Financial Accounting Standards Board (FASB) released in September 2006, Financial Accounting Standard No. 157, Fair Value Measurements (SFAS NO.157), defines three levels of inputs used in fair value measurement, through the fair value hierarchy to distinguish the reliability of fair value information, and to increase the information disclosure to make up for the fair value defects of measurement reliability.

In order to keep consistent convergence with international accounting standards and improve the quality of fair value information, the Ministry of Finance of the People's Republic of China issued Chinese Accounting Standards NO.39, Fair Value Measurements (CAS NO.39) in 2014, which provides theoretical basis and standard basis for the further expansion of the use of fair value. With the expansion of the range of fair value application, especially the expansion of the range of fair value measured with Level 2 and Level 3 inputs, the subjective judgment and uncertainty of fair value measurement increase, and the difficulty of the auditor's fair value audit increases.

There are difficulties in auditing fair value measurement projects, and the difficulty of fair value estimation is positively related to the audit cost. The more difficult the estimation is, the more complex the audit procedure is, the audit workload will increase significantly, which leads to the increase of audit cost (Bratten et al., 2013). The accounting standard system published in China in 2006 widely adopts fair value, which improves the quality of accounting information, but increases the difficulty of auditors' professional judgment, brings audit risks and increases the audit cost of certified public accountants (Yang Shuhuai, 2013). To select specific projects related to fair value (holding assets changes, changes in the fair value, the overall profit and loss, loss of asset impairment), Hao Yugui etc. (2014) find that they are positively related to the audit fees significantly, and audit expense contains the consideration of the risk of fair value estimation and the fair valuation of assets. Using banking firm-year observations from 2008 to 2015, Wang Shouhai et al. (2017) find that the larger the scale of financial assets and liabilities measured by fair value, the higher the fees charged by auditors; Moreover, the professional expertise of accounting firms enhances the positive correlation between fair value and audit fees. Ettredge et al. (2014) further study the three levels of fair value measurement and find that the relationship between fair value level and audit fees present a monotonously rising relationship, that is, the higher the level of fair value, the more significant the relationship between fair value and audit fees. From the perspective of earnings management, Zhu Song et al. (2010) and Ma Jianwei et al. (2012) also discuss the impact of fair value earnings management on audit fees, and find that the asset impairment representing the earnings management motivation and the proportion of financial assets available for sale is significantly positively associated with audit fees.

Most of existing literature come to the conclusion that with the increase of the complexity and decrease of the reliability of fair value measurement, the auditor takes more audit risk and requires the company to pay more audit expenses, which supports the risk determinism of audit expenses.

It is worth noting that the fair value in China has experienced twists and turns, and the lack of fair value determination of active market price is the focus of attention of market investors and securities regulatory authorities. Will this have an impact on the hierarchy of fair value measurement? Will this affect the auditor's efforts?

We estimate the audit fee model using the data of listed companies in the banking industry from 2007 to 2016. Consistent with our expectations, we find that the total assets and liabilities measured by fair value are positively associated with audit expenses, and the fair-valued assets and liabilities are positively associated with audit expenses, respectively. Moreover, the positive association between audit fees and the fair value obtained via Level 2 or Level 3 inputs is greater than that Level 1. This conclusion further validates the hypothesis that the difficulty of verifying the fair value measurement does increase the audit effort. Different from the existing literature, we do not find that the coefficients and t-statistics increase monotonically for fair-valued asset and liabilities based on Level 1 inputs, Level 2 inputs, and Level 3 inputs, respectively.

On the contrary, we find that fair-valued assets and liabilities measured by Level 2 inputs have a positive and statistically significant coefficient in the audit fees model, and the coefficient is greater than the coefficients of fair-valued assets and liabilities measured by Level 1 and Level 3 inputs.

As the proportion of fair value based on Level 2 inputs is the highest and the balance is the largest, the auditors need to pay more audit efforts directly, which supports the scale determinism of audit expenses. We didn't find that the coefficients and t-statistics for the fair value based on Level 3 inputs is the largest, the possible reasons due to the impact of professional judgment on 
the fair value hierarchy and the absence of corresponding supervision, the management has the motivation to use hierarchy for earnings management.

In summary, we examine the association between audit fees and the fair-valued assets and liabilities held by the sample of Chinese listed banking companies. Based on the application background of fair value in China, we prove the scale determinism of audit expenses from the perspective of fair value hierarchy. It is found that the management may carry out earnings management through the conversion between fair value hierarchies, thus affecting the audit fees, which enriched the research literature of fair value influencing audit fees. Our results also contribute to the understanding of audit fee determinants in the banking industry that has been neglected in the audit fees research literature.

\section{Hypotheses Development}

Fair value is a measurement based on the market inputs, and the market price is the best estimate of fair value. However, in the absence of an active market, the evaluation of fair value based on non-observable inputs requires the subjective judgment and estimation of the management. The management should provide valuation parameters, select valuation techniques, or comprehensively apply a variety of valuation techniques, and assign appropriate weight to them. All these are influenced by the management's own professional background and knowledge structure. Unreasonable valuation parameter selection and inappropriate valuation model often lead to large differences in fair value valuation. Moreover, based on the Principal-Agent Theory, the management, as the party with information advantage, often manipulates the accounting profit by subjective judgment and estimation of fair value valuation against the client's will to improve the financial performance in order to maximize its own interests. Compared with the historical cost, auditing fair value data usually requires knowledge of finance and economics other than accounting, and requires more efforts from auditors of higher level, expertise or experience (Cai Li etc., 2018), judge whether the valuation method is reasonable and appropriate. At the same time, when the macro economy is faced with risks, the market fluctuates a lot, and the risk of improper selection or application of valuation model to estimate the fair value is greater.

The higher the degree of uncertainty of fair value valuation, the greater the risk of material misstatement of fair value data. Auditors need to spend more audit resources, implement more audit procedures, or hire evaluation experts to reduce audit risk, which will result in higher audit costs and higher audit fees for auditors to compensate. In addition, faced with the high uncertainty of fair value items, auditors are bound to charge higher audit fees in order to protect themselves. Our first hypothesis is:

H1: All else being equal, assets and liabilities measured by fair value of listed Banks are positively associated with banks' audit fees.
According to the fair value hierarchy theory, the fair value based on Level 1 inputs has the highest reliability (unless the trading volume of the capital market is minimal or there is a sharp fluctuation), which is highly verifiable and less difficult to audit. Since there is no observable information such as the active market quotation of the same assets or liabilities for reference, the fair value based on Level 2 inputs needs to adjust the information such as the active market quotation of similar assets or liabilities, and the adjustment is mainly based on the subjective judgment of the management, which is difficult for auditors to verify (Melek Akgun et al., 2011). Especially for the Level 3 fair value, the key assumptions and parameters that have a significant impact on the measurement results are all non-observable parameters, and the management or external appraisers need a lot of subjective judgment and estimation in the valuation. Auditors not only need to have more knowledge and experience, but also usually need to utilize the work of internal and external valuation expert teams to assess whether the valuation methods and key assumptions adopted by management are reasonable, to determine the reliability of the Level 3 fair value (Dechow, 2010).

Therefore, with the increase of the level of fair value measurement, the assessors' subjective judgment and estimation increase, and the difficulty of auditors' review and verification of fair value increases. More audit resources are needed to reduce the audit risk to an acceptable low level, leading to the gradual increase of audit fees (Ettredge et al., 2014).

On the other hand, in Chinese capital market, although the concept of fair value hierarchy is introduced relatively late, and the fair value obtained via Level 2 and Level 3 inputs is constantly expanding, is there any specific situation different from that of the international capital market, so as to have different impacts on audit fees?

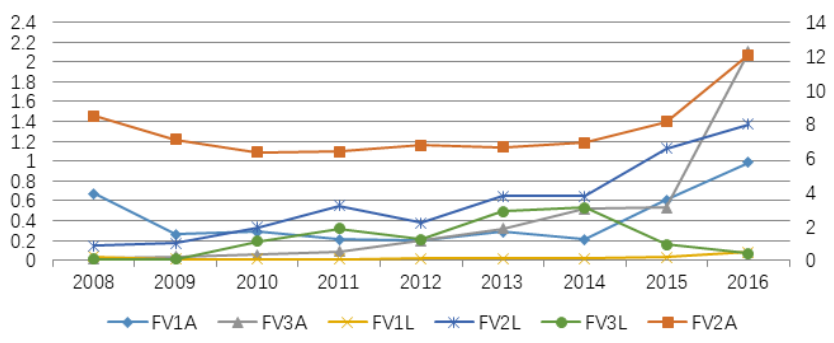

Figure 1. Level of fair value of listed banks in China $(\%)$.

This figure provides the fair value hierarchy of Chinese listed banking companies since 2007, in which FV1A, FV2A and FV3A (FV1L, FV2L and FV3L) respectively represent the proportion of fair value assets (liabilities) obtained via Level 1, Level 2 and Level 3 inputs to the total assets (total liabilities). Since the dimension of FV2A is large, the auxiliary scale on the right side is used in the figure, and the scale on the left side is used for other variables. Data are from the annual report of listed Banks.

As can be seen from figure 1, the fair-valued assets and liabilities are mainly based on Level 2 inputs, and 
the application scope of fair value obtained using Level 2 and Level 3 inputs is increasing.

In terms of the proportion of fair-valued assets in the total assets, the proportion of Level 1 fair value is overall low and relatively stable after 2007 , the proportion of Level 3 fair value is slowly rising, and the proportion of Level 2 fair value is the highest in each year and on an increasing trend, reaching $12.5 \%$ in 2016 . Although the proportion of fair-valued liabilities in the total liabilities is relatively low, the proportion of Level 2 fair values is the highest, which is similar to the situation where assets are measured by fair value.

Among the fair-valued assets and liabilities, the proportion of Level 2 fair value is the highest, and the balance is the largest. Besides the market factors, is it possible to be influenced by non-technical factors?

Firstly, accounting standards need to use professional judgment to distinguish fair value levels, leaving room for earnings management. According to the Fair Value Measurements (CAS NO.39), the inputs obtained for Level 2 fair value measurement is determined to be observable inputs based on the market, but needs to be adjusted. The Level 3 fair value is based entirely on unobservable inputs. However, professional judgment is needed in the differentiation. For example, according to the standard, the hierarchical attribution of the measurement result of fair value should be based on the lowest level of the inputs that is important to the measurement of fair value as a whole, and the important evaluation completely depends on the professional judgment of the management.

Secondly, management has incentives to reduce the measurement and disclosure of Level 3 fair value. The value relevance of Level 3 fair value is relatively weak, which may underestimate the market value of companies (Song et al., 2010). Furthermore, according to the fair value hierarchy, the higher the level of fair value, the more information to be disclosed. On the contrary, the Level 2 fair value is the transition of Level 1 and Level 3, which is flexible, has little impact on the market value of the enterprise, and low cost of information disclosure. Therefore, management has an incentive to increase the Level 2 fair value by reducing the Level 3 fair value.

Finally, there are still deficiencies in the supervision of the classification of fair value hierarchy. The use of fair value in China has experienced twists and turns, and the measurement of fair value in the absence of market price has always been the focus of supervision. In recent years, the documents and regulatory reports related to fair value issued by China Securities Regulatory Commission focus on the fair value valuation, but have not yet involved in the classification of fair value hierarchy.

In short, on the one hand, when the fair value needs to be estimated, due to the complexity of the valuation technology itself, the difficulty in applying the measurement model, and the subjective nature of valuation model, the fair value measurement items have higher inherent risks and the difficulty in auditing (Bratten et al., 2013). On the other hand, the fair value is widely used and becomes a tool of earnings management. Level 2 fair value accounts for the largest proportion of assets or liabilities, which may be the result of the management's earnings management, and increases the audit cost (Wu Lina, 2003).

Therefore, we propose two competing hypothesis:

H2a: All else being equal, the positive association between banks' audit fees and banks' fair-valued assets or liabilities is strongest for assets or liabilities based on Level 3 inputs.

$\mathrm{H} 2 \mathrm{~b}$ : All else being equal, the positive association between banks' audit fees and banks' fair-valued assets or liabilities is strongest for assets or liabilities based on Level 2 inputs.

\section{Data and Research Design}

\subsection{Data}

Our data cover the years 2007-2016. We obtain financial data from Wind Financial Information, and collect banking business data such as non-performing loan ratio, liquidity ratio, write-off of bad debts, capital adequacy, and fair value levels data from annual report of listed company. We require firm-year observations to have non-missing, non-zero audit fee data. These procedures leave us with 143 firm-year observations (25 unique firms) for our levels tests.

\subsection{Research Design and Variable Measurement}

We refer to the model of Ettredge et al. (2013) and Wang Shouhai et al. (2017) to build the banking industry audit fees basic model of this paper. We estimate the following equation (1) using pooled data for years 2007-2016. In model (1), fair value variables (FV, FV1, FV2, FV3) are the test variables.

$\mathrm{FEE}=\alpha_{0}+\alpha_{1} \mathrm{FV}+\alpha_{2} \mathrm{LEV}+\alpha_{3} \mathrm{ROA}+\alpha_{4} \mathrm{NOLOAN}+\alpha_{5} \mathrm{CH}$ $\mathrm{GOFF}+\alpha_{6} \mathrm{CAPRATIO}+\alpha_{7} \mathrm{INTANG}+\alpha_{8} \mathrm{BIG} 4+\alpha_{9} \mathrm{LIQRAT}$ $\mathrm{IO}+\alpha_{10} \mathrm{YEAR}+\varepsilon$

The dependent variable is FEE, which is the natural-log-transformed value of audit fees from annual report of listed company. The variables of interest are $\mathrm{FV}$, which are defined as the natural-log-transformed value of total fair-valued assets and liabilities amounts. To test H2, we replace FV with FV1, FV2 and FV3, to construct model (2), which are defined as the natural-log-transformed value of fair-valued assets and liabilities amounts measured using Level 1, Level 2, and Level 3 inputs, respectively.

For the selection of control variables, refer to Ettredge et al. (2013), Wang Shouhai et al. (2017). LEV is total liabilities divided by total assets, ROA is net profit divided by total assets, NOLOAN is Bad loans divided by total loans, CHGOFF is Annual write-off of bad loans divided by loans impairment provisions, CAPRATIO is own assets divided by risky assets, INTANG is the natural-log-transformed value of the year-end balance of intangible assets, LIQRATIO is the balance of liquid assets divided by the balance of liquid liabilities, which measure operating risk, credit risk, 
capital risk and liquidity risk respectively. When the annual report of the listed bank is audited for the Big4 audit firms, BIG4 takes the value of one, otherwise it is 0 . All continuous variables are winsorized at the 1\% and $99 \%$ levels each year. To test H1 (H2), we test whether the coefficient on FV (FV1, FV2 and FV3) differs from zero.

\section{Descriptive Statistics and Empirical Results}

\subsection{Descriptive Statistics}

TABLE I. DESCRIPTIVE STATISTICS FOR THE FULL SAMPLE

\begin{tabular}{c|c|c|c|c|c|c}
\hline & \multicolumn{1}{l|}{ Max } & Min & Mean & P50 & SD & N \\
\hline FEE & 11.74 & 4.500 & 7.145 & 6.685 & 1.594 & 143 \\
\hline FV & 15.21 & 0 & 11.71 & 12.18 & 3.002 & 143 \\
\hline FV1 & 12.47 & 0 & 3.339 & 0 & 4.936 & 143 \\
\hline FV2 & 15.14 & 0 & 11.57 & 11.98 & 2.960 & 143 \\
\hline FV3 & 13.40 & 0 & 3.406 & 0 & 4.806 & 143 \\
\hline LEV & 0.970 & 0.900 & 0.938 & 0.940 & 0.0121 & 143 \\
\hline ROA & 0.014 & 0.0013 & 0.0101 & 0.0103 & 0.00195 & 143 \\
\hline NOLOAN & 0.0564 & 0.0038 & 0.0116 & 0.0105 & 0.00578 & 143 \\
\hline CHGOFF & 523.4 & 0 & 16.87 & 7.420 & 45.08 & 143 \\
\hline CAPRATIO & 0.201 & 0.0577 & 0.123 & 0.121 & 0.0182 & 143 \\
\hline INTANG & 10.19 & 0 & 6.626 & 6.779 & 2.384 & 143 \\
\hline BIG4 & 1 & 0 & 0.902 & 1 & 0.298 & 143 \\
\hline LIQRATIO & 0.786 & 0.271 & 0.441 & 0.440 & 0.0968 & 143 \\
\hline
\end{tabular}

TABLE I provides the descriptive statistics of variables used in our tests (pooled for years 2007-2016).
FEE has mean (median) value of 7.145 (6.685) with a low standard deviation (1.594), suggesting that the variation in banking audit fees is modest. Total, Level 1 , Level 2, and Level 3 fair-valued assets and liabilities are, on average, $11.71,3.339,11.57$ and 3.406 , respectively. LEV of the banking industry is generally high, with an average of $93.8 \%$. The average ROA is $1.01 \%$ and the lowest is $0.013 \%$. The overall profitability of the banking industry is relatively low. The average CAPRATIO is $12.3 \%$; the minimum value of LIQRATIO is $27.07 \%$, which meets the regulatory standard (more than 25\%). 90.2\% of the listed banks are audited by the international Big4 audit firms.

The Pearson correlation coefficient of FEE with the fair-valued total assets and liabilities (FV) is positive and significant, which is consistent with the expectation of hypothesis 1 . There is a positive correlation between fair value measured by Level 1 to 3 inputs and FEE, and fair value obtained via Level 2 inputs has the highest correlation coefficient among the three levels. Whether it is audited by the international Big4 audit firms or not and the balance of INTANG are significantly positively correlated with FEE. Since there is no quantitative relationship between variables, it needs to be further confirmed by regression.

TABLE II . PEARSON CORRELATION COEFFICIENTS AMONG VARIABLES

\begin{tabular}{c|c|c|c|c|c|c|c|c|c|c|c|c|c}
\hline & FEE & FV & FV1 & FV2 & FV3 & LEV & ROA & NOLOAN & CHGOFF & CAPRATIO & INTANG & BIG4 & LIQRATIO \\
\hline FEE & 1 & & & & & & & & & & & & \\
\hline FV & $0.798^{* * *}$ & 1 & & & & & & & & & & & \\
\hline FV1 & $0.681^{* * *}$ & $0.701^{* * *}$ & 1 & & & & & & & & & & \\
\hline FV2 & $0.806^{* * *}$ & $0.973^{* * *}$ & $0.668^{* * *}$ & 1 & & & & & & & & & \\
\hline FV3 & $0.660^{* * *}$ & $0.720^{* * *}$ & $0.592^{* * *}$ & $0.652^{* * *}$ & 1 & & & & & & & & \\
\hline LEV & -0.118 & $-0.174^{* *}$ & -0.136 & $-0.168^{* *}$ & $-0.232^{* * *}$ & 1 & & & & & & & \\
\hline ROA & $0.459^{* * *}$ & $0.396^{* * *}$ & $0.211^{* *}$ & $0.438^{* * *}$ & $0.362^{* * *}$ & $-0.351^{* * *}$ & 1 & & & & & & \\
\hline NOLOAN & $0.141^{*}$ & $0.162^{*}$ & $0.227^{* * *}$ & 0.119 & 0.136 & $-0.167^{* *}$ & $-0.224^{* * *}$ & 1 & & & & & \\
\hline CHGOFF & -0.119 & -0.0950 & -0.0300 & -0.113 & -0.0860 & 0.0430 & $-0.193^{* *}$ & 0.0700 & 1 & & & & \\
\hline CAPRATIO & $0.147^{*}$ & $0.187^{* *}$ & $0.167^{* *}$ & $0.152^{*}$ & 0.0830 & $-0.701^{* * *}$ & $0.367^{* * *}$ & 0.0100 & -0.112 & 1 & & & \\
\hline INTANG & $0.702^{* * *}$ & $0.665^{* * *}$ & $0.581^{* * *}$ & $0.678^{* * *}$ & $0.663^{* * *}$ & $-0.145^{*}$ & $0.364^{* * *}$ & 0.0940 & -0.0520 & -0.0890 & 1 & & \\
\hline BIG4 & $0.325^{* * *}$ & $0.438^{* * *}$ & $0.326^{* * *}$ & $0.417^{* * *}$ & $0.378^{* * *}$ & -0.0220 & $0.248^{* * *}$ & -0.0290 & -0.0240 & -0.0110 & $0.329 * * *$ & 1 & \\
\hline LIQRATIO & -0.123 & -0.0660 & $0.157^{*}$ & -0.101 & 0.0100 & $-0.277^{* * *}$ & -0.0410 & $0.141^{*}$ & $0.189^{* *}$ & $0.246^{* * *}$ & -0.0620 & -0.0200 & 1 \\
\hline
\end{tabular}




\subsection{Empirical Results for $\mathrm{H} 1$ and $\mathrm{H} 2$}

TABLE III. The RESUlts of OLS ESTIMATION OF EQUATION

\begin{tabular}{c|c|c|c|c|c}
\hline DV=FEE & Model(1) & Model(2) & DV=FEE & Model(1) & Model(2) \\
\hline Variables & Coef.(Robust T) & Coef(Robust T) & Variables & Coef(Robust T) & Coef(Robust T) \\
\hline INTERCEPT & $-20.49(-1.51)$ & $-18.69(-1.56)$ & CAPRATIO & $28.49^{* *}(2.88)$ & $25.94^{* *}(2.77)$ \\
\hline FV & $0.189^{* *}(4.11)$ & & INTANG & $0.312^{* * *}(5.27)$ & $0.243^{* * *}(4.32)$ \\
\hline FV1 & & $0.0374^{*}(2.40)$ & BIG4 & $-0.399(-1.22)$ & $-0.367(-1.27)$ \\
\hline FV2 & & $0.161^{* * *}(3.61)$ & LIQRATIO & $0.289(0.44)$ & $-0.194(-0.29)$ \\
\hline FV3 & & $0.0619^{* *}(2.82)$ & YEAR & Control & Control \\
\hline LEV & $17.09(1.28)$ & $17.08(1.45)$ & N & 143 & 143 \\
\hline ROA & $153.0^{*}(2.53)$ & $118.8(1.94)$ & F & $25.23^{* * *}$ & $26.69^{* * *}$ \\
\hline NOLOAN & $161.4^{* * *}(5.94)$ & $130.0^{* * *}(4.70)$ & $R^{2}$ & 0.772 & 0.794 \\
\hline CHGOFF & $0.0057^{* * *}(5.21)$ & $0.0048^{* * *}(4.22)$ & adj.R & 0.740 & 0.761 \\
\hline
\end{tabular}

TABLE III presents the results of OLS regressions of FEE on fair value measurement test variables with observations pooled over years. Standard errors and t-statistics are adjusted for heteroskedasticity. *,**, and $* * *$ indicate statistical significance at $5 \%, 1 \%$ and $0.1 \%$ levels (two-sided) respectively.

The $\mathrm{F}$ values of the two regression equations are significant at the $0.1 \%$ level, and the model fit well. The variance inflation factor (VIF) of multi-collinearity test is lower than 2 , and there is no serious collinearity problem.

Model (1) of TABLE III tests H1, i.e. whether the coefficient on the fair-valued total assets and liabilities (FV) differs from zero. The coefficient on FV is 0.189 , which is significantly positive at the $0.1 \%$ level, indicating that the fair value has a significant impact on the audit fees, thus rejecting the null.

Model (2) of TABLE III test $\mathrm{H} 2$ by breaking FV into FV1, FV2, and FV3, and investigating whether the coefficients on these variables differ from each other. The coefficients (t-statistics) of FV1, FV2, and FV3 are $0.0374(\mathrm{t}=2.4), 0.161 \quad(\mathrm{t}=3.61)$, and $0.0619 \quad(\mathrm{t}=2.82)$, respectively. In terms of both coefficient and significance level, the fair value obtained via Level 2 or Level 3 inputs is greater than that Level 1, indicating that when the fair value needs to be estimated, the auditor needs to pay more audit resources and require more audit fees to compensate.

Moreover, the coefficient and significance level on FV2 $(0.161$ and $0.1 \%)$ are greater than those on FV3 $(0.0619$ and $5 \%)$, the positive association between banks' audit fees and banks' fair-valued assets or liabilities is strongest for assets or liabilities based on Level 2 inputs. Hypothesis H2b is verified.

Furthermore, model(1) and model(2) are respectively regressed by assets and liabilities. The regression results are shown in TABLE IV and TABLE V. 
TABLE IV. THE RESULTS OF OLS ESTIMATION OF EQUATION: FAIR-VALUED ASSETS

\begin{tabular}{c|c|c|c|c|c}
\hline DV=FEE & Model(1) & Model(2) & DV=FEE & Model(1) & Model(2) \\
\hline Variables & Coef.(Robust T) & Coef.(Robust T) & Variables & Coef.(Robust T) & Coef.(Robust T) \\
\hline INTERCEPT & $-17.67(-1.21)$ & $7.293(0.83)$ & CAPRATIO & $27.85^{* *}(2.73)$ & $9.855(1.90)$ \\
\hline FVA & $0.409^{* *}(3.47)$ & & INTANG & $0.256^{* * *}(5.05)$ & $0.190^{* * *}(4.31)$ \\
\hline FVA1 & & $0.0217(1.10)$ & BIG4 & $0.150(0.47)$ & $-0.351(-1.51)$ \\
\hline FVA2 & & $0.644^{* * *}(8.30)$ & LIQRATIO & $0.262(0.40)$ & $-0.210(-0.37)$ \\
\hline FVA3 & & $0.0471^{*}(2.42)$ & YEAR & Control & Control \\
\hline LEV & $13.46(0.92)$ & $-10.70(-1.21)$ & N & 143 & 143 \\
\hline ROA & $55.63(0.78)$ & $-102.8(-1.85)$ & F & $27.93^{* * *}$ & $34.61^{* * *}$ \\
\hline NOLOAN & $154.0^{* * *}(5.34)$ & $109.2^{* * *}(4.62)$ & $\mathrm{R}^{2}$ & 0.791 & 0.856 \\
\hline CHGOFF & $0.00266^{*}(2.04)$ & $0.00081(0.78)$ & adj.R $R^{2}$ & 0.762 & 0.834 \\
\hline
\end{tabular}

TABLE IV presents the results of OLS regression of $\log$ of audit fees (FEE) on fair-valued assets. FVA, FVA1, FVA2, and FVA3 are $\log$ of fair-valued total

assets, assets using Level 1, Level 2, and Level 3 inputs, respectively.

TABLE V. THE RESULTS OF OLS ESTIMATION OF EQUATION: FAIR-VALUED LIABILITIES

\begin{tabular}{c|c|c|c|c|c}
\hline DV=FEE & Model(1) & Model(2) & DV=FEE & Model(1) & Model(2) \\
\hline Variables & Coef.(Robust T) & Coef.(Robust T) & Variables & Coef.(Robust T) & Coef.(Robust T) \\
\hline INTERCEPT & $-28.23^{*}(-2.11)$ & $-25.21^{*}(-2.15)$ & CAPRATIO & $25.13^{*}(2.30)$ & $21.51^{*}(2.12)$ \\
\hline FVL & $0.174^{* *}(4.88)$ & & INTANG & $0.234^{* *}(3.35)$ & $0.159^{*}(2.42)$ \\
\hline FVL1 & & $0.0812^{* *}(3.10)$ & BIG4 & $-0.138(-0.52)$ & $-0.151(-0.65)$ \\
\hline FVL2 & & $0.146^{* * *}(4.04)$ & LIQRATIO & $-0.716(-1.11)$ & $-1.127(-1.78)$ \\
\hline FVL3 & & $0.0838^{* * *}(3.38)$ & YEAR & Control & Control \\
\hline LEV & $27.15^{*}(2.10)$ & $25.72^{*}(2.29)$ & N & 143 & 143 \\
\hline ROA & $163.9^{*}(2.47)$ & $139.1^{*}(1.98)$ & F & $24.97^{* * *}$ & $24.91^{* *}$ \\
\hline NOLOAN & $154.9^{* *}(5.71)$ & $126.3^{* *}(4.60)$ & $\mathrm{R}^{2}$ & 0.759 & 0.789 \\
\hline CHGOFF & $0.00565^{* * *}(4.74)$ & $0.00478^{* *}(3.74)$ & adj. $R^{2}$ & 0.726 & 0.756 \\
\hline
\end{tabular}

TABLE $\mathrm{V}$ presents the results of OLS regression of $\log$ of audit fees (FEE) on fair-valued liabilities. FVL, FVL1, FVL2, and FVL3 are $\log$ of fair-valued total liabilities, liabilities using Level 1, Level 2, and Level 3 inputs, respectively.

For both assets and liabilities, the fair-valued assets and liabilities are positively associated with audit fees, and the positive association between audit fees and the fair value obtained via Level 2 or Level 3 inputs is greater than its positive association with the fair value using Level 1 inputs.

Not consistent with existing research, the fair-valued assets and liabilities measured by Level 2 inputs have a positive and statistically significant coefficient in the audit fee model, and the coefficient is greater than the coefficients of fair-valued assets and liabilities measured by Level 3 inputs.

The possible explanation is that Level 2 fair value accounts for the largest proportion of assets or liabilities, which supports the scale determinism of audit expenses.
In addition, accounting standards leave room for earnings management, and management has incentives to reduce the measurement and disclosure of Level 3 fair value, the supervision of the classification of fair value hierarchy is still deficiencies. Level 2 fair value may represent the management's earnings management on fair value hierarchy, which increases the audit risk and the auditor allocates more audit resources, resulting in the increase of audit fees.

\subsection{Robustness Test}

This paper carries out robustness test from the following two aspects: The audit fees and fair value variables (FV, FV1, FV2, FV3) are deflated by total assets and total liabilities of model(1) and model(2),respectively. Operating risk is measured by the rate of return on net assets instead of the rate of return on total assets. The results of OLS regression show that all results remain basically unchanged. 


\section{Conclusions}

Using Chinese listed commercial bank data from 2007 through 2016, this paper discusses the relationship between fair value hierarchy and audit fees. Consistent with the view that audit risk and effort increase with the extent of fair-valued assets and liabilities, we provide evidence that auditors charge more for the uncertainty and risk of fair value. Furthermore, within fair-valued assets and liabilities, the positive association between logged audit fees and the total assets and liabilities that are fair-valued using Level 2 or Level 3 inputs is greater than its positive association of total assets and liabilities that are fair-valued using Level 1 inputs.

In particular, our study didn't find a monotonously rising relationship between fair value hierarchy and audit fees (Ettredge et al., 2014). The coefficient of fair value obtained via Level 2 inputs is greater than the coefficients of fair value measured by Level 3 inputs in the audit fee model. This supports the scale determinism of audit expenses. It also indicates that the management of Chinese listed commercial bank may carry out earnings management by dividing the fair value hierarchy, which leads to the high audit risk and the increase of audit fees.

Due to the shortage of research, it is difficult to obtain public data from fair value hierarchical transformation, and it is difficult to directly test the use of hierarchical transformation (especially from the Level 3 to Level 2) for earnings management, which challenges the hypothesis of fair value representation of earnings management at Level 2 proposed in this paper. At the same time, the samples selected in this paper are listed companies in the banking industry, and the sample size is relatively small, which has the limitation of insufficient sample size.

Our research suggests further improving the fair value measurement standards, providing detailed implementation guidelines for the fair value valuation method and fair value level disclosure, enhancing the operability of the fair value measurement standards, reducing the management earnings management room, and timely revising fair value measurement audit standards to provide applicable guidance for auditors to carry out fair value audit.

We believe that fair value measurement and disclosure are faced with great risk and uncertainty, and it is urgent to formulate internal control standards for fair value measurement and disclosure to unify fair value process control, improve the control environment for the implementation of fair value accounting, and promote enterprises to standardize the implementation of fair value accounting.

Our research also suggests that securities regulatory authorities should continuously strengthen the supervision of fair value information disclosure while paying attention to the measurement of fair value, especially for fair value obtained using Level 3 inputs.

\section{References}

[1] Simunic, D.A..(1980). The pricing of audit services: theory and evidence. J. Journal of Accounting Research, Vol.18 Iss.1:161-190.

[2] Hay, D. C., Knechel, W. R., \& Wong, N. (2006). Audit fees: A meta-analysis of the effect of supply and demand attributes. J. Contemporary Accounting Research, Vol.23 Iss.1: 141-191.

[3] Fields, L. P., Fraser, D. R., \& Wilkins, M. S. (2004). An investigation of the pricing of audit services for financial institutions. J. Journal of Accounting and Public Policy, Vol.23 Iss.1: 53-77.

[4] Wu Lina, (2003).The Determinants of Audit Fee: Evidence from Chinese Stock Market's First time Disclosure of Audit Fee .J. China Accounting Review, Vol.1, No.1:113-128.

[5] Pan Keqin, (2008).Corporate Governance, Audit Risk and Audit Pricing: Empirical Evidence Based on CCGINK. J. Nankai Management Review, Vol.11, No.1:106-112.

[6] Gai Di, Sheng Changyan, (2013), Influence of Defect and Correction of Internal Control on Audit Fees: Data form China A-Share Listed Companies, J. Journal of Audit and Economic Research, Vol.28, No.3:21-27.

[7] Vera Palea, (2014),Fair value accounting and its usefulness to financial statement users, J. Journal of Financial Reporting and Accounting, Vol. 12 Iss. 2:102 - 116 .

[8] Bratten, B., Gaynor, L. M., McDaniel, L., Montague, N. R., \& Sierra, G. E. (2013). The audit of fair values and other estimates: The effects of underlying environmental, task, and auditor-specific factors. J. Auditing: A Journal of Practice and Theory, Vol.32 (Supplement No. 1):7-44.

[9] Yang Shuhuai, (2013), Influence of Fair Value Measurement on Auditing Fee and Auditing Quality: An Empirical Analysis of A-Share Listed Companies during 2003-2010, J. Contemporary Financial Magazine, Iss.2:119-129.

[10] Hao Yugui, Zhao Kuankuan, Hao zheng, (2014), Research on Fair Value. Fluctuation of Assets' Value and Audit Fees: Based on the Empirical Evidences of Listed Companies in ShangHai and ShenZhen Stock Markets from 2009 to 2012,J. Journal of Nanjing Audit University, Iss.1:97-106.

[11] Wang Shouhai, Liu Zhiqiang, (2017), Fair Value, Industry Expertise and Audit Fees. J. Journal of audit research. Iss.2:48-56.

[12] Ettredge, M., Xu, Y., \& Yi, H. (2014). Fair value measurements and audit fees: Evidence from the banking industry. J. Auditing: A Journal of Practice and Theory, Vol. 33 Iss.3: 33-58.

[13] Zhu Song, $\mathrm{Xu}$ Haofeng , Wang Shuang,(2010) .Audit Pricing under the Fair Value Principle, J. Journal of audit and economic research, Vol.25, Iss.4:29-36. 
[14] Ma Jianwei, Yang Yajun, Huang Wen, (2012). Research on the Correction between Classification of Financial Assets Measured by Fair Value and Audit Fee Evidence. J, Journal of central university of finance and economics, Iss.11:85-90.

[15] Cai Li, Tang Jiawei, Cai cun. (2018). Fair Value Measurement, Earnings Management, and Auditor Coping Strategies. J, Journal of Accounting Research, Iss.11:85-91.

[16] Melek Akgun, Davut Pehliranli and Meltem Gurunlu. 2011. A Process Design for Auditing Fair
Value. J. Intermational Jourmal of Economics and Finance, Vol.3 Iss.3:160-166.

[17] Dechow P M, Myers L A, Shakespeare C. (2010).Fair value accounting and gains from asset securitizations: a convenient earnings management tool with compensation side-benefits. J. Journal of Accounting and Economics, Vol.49, Iss.1: 2-25.

[18] Chang Joon Song, Wayne B. Thomas, Han Yi .Value Relevance of FAS No.157 Fair Value Hierarchy Information and the Impact of Corporate Governance Mechanisms. J. The Accounting Review Vol. 85, No. 4:1375-1410. 